\title{
Isozyme, Randomly Amplified Polymorphic DNA (RAPD), and Restriction Fragment-length Polymorphism (RFLP) Markers Used to Deduce a Putative Parent for the 'Braeburn' Apple
}

\author{
S.E. Gardiner, H.C.M. Bassett, and C. Madie \\ The Horticulture and Food Research Institute of New Zealand, Batchelar Research Centre, Private Bag \\ 11 030, Palmerston North, New Zealand \\ D.A.M. Noiton \\ The Horticulture and Food Research Institute of New Zealand, Havelock North Research Centre, Private \\ Bag 1401, Havelock North, New Zealand
}

Additional index words. Malus domestica, genetic distance, chemiluminescent, biochemical markers, molecular markers

\begin{abstract}
Information about a rare allele of phosphoglucomutase (PGM) that is shared by 'Braeburn' and 16\% of cultivars in the New Zealand Cultivar Collection was combined with historical information about cultivar distribution to select a set of 15 cultivars for a more detailed genetic analysis of their relatedness to the key New Zealand apple (Malus domestica Borkh.) 'Braeburn'. DNA from all 16 cultivars was examined by RFLP analysis using 41 probe-enzyme combinations and also by RAPD analysis with 39 selected primers. The RFLP and RAPD data excluded a proposal that 'Lady Hamilton' and 'Braeburn' are genetically identical. All cultivars except 'Lady Hamilton' were excluded as potential parents for 'Braeburn' based on incompatible RFLP banding. Assessment of genetic distances between 'Braeburn' and the other 15 cultivars from RFLP and RAPD data demonstrated that 'Lady Hamilton' was more closely related to 'Braeburn' than all others. We conclude that there is a high likelihood that 'Lady Hamilton' is one of the parents of 'Braeburn'.
\end{abstract}

'Braeburn' is one of the most important export apple cultivars currently grown in New Zealand. It has desirable appearance, texture, and flavor and good storage quality but requires specific cultural management practices to avoid problems with bitter pit and brownheart (Taylor, 1995).

Identifying the parents of 'Braeburn' can provide useful information to apple breeders. 'Braeburn' originated as a chance seedling found in an orchard in the Upper Moutere region near Nelson, New Zealand, in 1952 (Taylor, 1995). Although there has been speculation about its parentage, it has not been verified. Records of apple cultivars grown in Nelson at that time are incomplete, although it is known that 'Lady Hamilton' had been growing in an adjoining orchard and is widely believed to be one of the parents of 'Braeburn', or even be identical with 'Braeburn'.

Previous reports on using biochemical and molecular markers for parentage studies in plants include the following: isozymes (Chyi and Weeden, 1984), RFLPs (Adato et al., 1995; Nybom, 1990; Nybom and Schaal, 1990; Nybom et al., 1992; Watillon et al., 1991), and RAPD markers (Boury et al., 1992; Harada et al., 1993; Landry et al., 1994). Noli et al. (1995) suggested that analysis of genetic relationships must not rely exclusively on any single marker system that targets a portion of the genome only. In our study, we used a combination of isozyme, RFLP, and RAPD markers to identify a likely candidate ('Lady Hamilton') as one of the parents of 'Braeburn'.

Received for publication 24 Oct. 1995. Accepted for publication 15 May 1996. This work was supported in part by a grant from ENZA New Zealand (International). We thank Rod Ball for the statistical analysis and gratefully acknowledge Richard Forster and Erik Rikkerink for critically reviewing the manuscript. The cost of publishing this paper was defrayed in part by the payment of page charges. Under postal regulations, this paper therefore must be hereby marked advertisement solely to indicate this fact.

\section{Materials and Methods}

Plant material. Young, expanding leaves were harvested from trees maintained in the HortResearch Cultivar Collection in early Spring 1994 and either were used fresh (for isoenzyme analyses) or stored (at $-70{ }^{\circ} \mathrm{C}$ until needed) for DNA isolation. For isozyme analysis, 186 cultivars were used, while for RFLP and RAPD analysis, 16 cultivars were used.

Isozyme analysis. Leaf tissue was crushed in an extraction buffer consisting of $0.1 \mathrm{M}$ tris- $\mathrm{HCl}, \mathrm{pH} 7.0 ; 0.8 \mathrm{~m}$ sodium thioglycolate; $0.1 \mathrm{M}$ dithiothreitol; $0.1 \mathrm{M}$ dithioerythritol; $0.1 \%$ ascorbic acid; and $0.014 \mathrm{M}(\beta$-mercaptoethanol; $10 \% \mathrm{w} / \mathrm{v}$ polyvinylpyrrolidone-40 (PVP-40) (modified from Weeden and Lamb, 1985). Extracts were loaded onto an $11 \%$ starch gel made with $0.022 \mathrm{ML}$-histidine-citrate, $\mathrm{pH} 6.5$, and were electrophoresed in $0.065 \mathrm{~m} \mathrm{~L}$-histidine-citrate at $300 \mathrm{~V}$ at $4{ }^{\circ} \mathrm{C}$ for $5 \mathrm{~h}$. Gel slices were assayed for phosphoglucomutase (PGM) following the procedures of Wendel and Weeden (1989).

DNA isolation. Two leaves ( $<1.5 \mathrm{~cm}$ long) were ground in a sealed plastic bag with $2 \mathrm{~mL}$ of extraction buffer ( $140 \mathrm{~mm}$ sorbitol; 220 mm tris- $\mathrm{HCl}$, pH 7.5; 20 mм Na $\mathrm{EDTA}_{2}$; $0.8 \mathrm{M} \mathrm{NaCl}$; 0.8\% w/ $\mathrm{v}$ cetyl trimethylammonium bromide; $1 \% \mathrm{w} / \mathrm{v} \mathrm{N}$-lauroylsarcosine; and $1 \% \mathrm{w} / \mathrm{v}$ polyvinylpyrrolidone). A $1.6-\mathrm{mL}$ sample of the resulting pulp was extracted with $0.4 \mathrm{~mL}$ of 24 chloroform : 1 octanol (v/v) at $65^{\circ} \mathrm{C}$ for $30 \mathrm{~min}$ and centrifuged at $14,000 \times \mathrm{g}$ for $10 \mathrm{~min}$. DNA was precipitated from the aqueous layer by adding $1 \mathrm{~mL}$ ice-cold isopropanol. The DNA pellet was recovered following a 5-min centrifugation at $12,000 \times \mathrm{g}$, washed twice with $70 \%$ ethanol, dried under vacuum, and resuspended in $0.1 \mathrm{~mL}$ of steriledistilled water. DNA quantitation was by visual comparison of DNA dilutions electrophoresed on $0.9 \%$ Ultrapure (Life Technologies, Gaithersburg, Md.) agarose gels in TAE with $50 \mathrm{ng}$ of lambda phage DNA (Life Technologies) as standard. Electro- 
phoresis runs were for $5 \mathrm{~cm}$ at $2.5 \mathrm{~V} \cdot \mathrm{cm}^{-1}$, and DNA staining was with $0.35 \mathrm{mg} \cdot \mathrm{mL}^{-1}$ ethidium bromide. Under these conditions apple DNA runs as a clear band at the same position on the gel as the standard.

RFLP analysis using chemiluminescent detection. Samples of apple leaf DNA (1.5 mg) digested with the restriction enzymes Bam HI, Bgl II, Eco RI, Eco RV, Dra I, Hind III, Pst I, or Xba I were electrophoresed on 1\% UltraPure (Life Technologies) agarose gels in TAE at $2.5 \mathrm{~V} \cdot \mathrm{cm}^{-1}$ for $18 \mathrm{~h}$, and blotted onto a Hybond $\mathrm{N}^{+}$ membrane (Amersham International plc, Buckinghamshire, England) using alkaline transfer in $0.4 \mathrm{~m} \mathrm{NaOH}$.

Probes from almond (Prunus amygdalus L.) were derived from genomic clones AG7, AG10, AG11, AG40, AG41, AG46, AG53, and cDNA clones AC27, extensin, and phosphoglyceromutase (PGlm) (provided by P. Arus, IRTA, Cabrils, Spain). Apple cDNA partial clones for alcohol dehydrogenase (pADH32) and triose phosphate isomerase (pBG10) were provided by G. Ross, a clone for aminocyclopropane carboxylate synthase (pAPAS) was a gift from M. Lay Yee, and a clone for ribulose bisphosphate carboxylase small subunit (parbcS2) was provided by L. Beuning, all of HortResearch, Auckland, New Zealand. All 41 probe-enzyme combinations used are listed in Table 1.

Hybridization at $42{ }^{\circ} \mathrm{C}$ was performed with probes labeled directly with horseradish peroxidase, and stringency washes were as described in the enhanced chemiluminescence (ECL) kit from Amersham International plc. A modified detection reaction was performed by quickly layering a membrane dried of surface moisture on a Whatman no. 3MM filter paper presoaked in detection reagent inside a plastic folder. The folder was heatsealed before exposure of a medical x-ray film (Fuji Photo Film Co., Tokyo) in a photographic cassette at room temperature for 1 to $4 \mathrm{~h}$, depending on the expected intensity of the detection reaction.

RAPD analyses. The PCR reaction mixtures $(12.5 \mu \mathrm{L})$ contained $10 \mathrm{~mm}$ tris- $\mathrm{HCl}$ (pH 8.8), $50 \mathrm{~mm} \mathrm{KCl}, 2.0 \mathrm{~mm} \mathrm{MgCl}_{2} 0.01 \%$ gelatin, $0.8 \%$ formamide, $0.1 \mathrm{~mm}$ each dNTP, $0.2 \mathrm{~mm}$ each primer, and $1 \mathrm{ng}$ of apple DNA, $1.2 \mathrm{U}$ of Taq polymerase (Stratagene, La Jolla, Calif.) and were overlaid with $14 \mathrm{~mL}$ paraffin. Amplification was conducted in a thermal cycler (Cetus; Perkin-Elmer, Rockwalk, Conn.) programmed for $4 \mathrm{~min}$ at $94^{\circ} \mathrm{C}, 40$ cycles of $1 \mathrm{~min}$ at $94^{\circ} \mathrm{C}$, $1 \mathrm{~min}$ at $40^{\circ} \mathrm{C}$, and $2 \mathrm{~min}$ at $72{ }^{\circ} \mathrm{C}$, followed by a final extension cycle of $10 \min 72^{\circ} \mathrm{C}$. These reaction conditions produce consistently reproducible results for a range of apple DNA concentra-

Table 1. Restriction enzymes and probes used in RFLP analyses of 15 apple cultivars.

\begin{tabular}{|c|c|c|c|c|c|c|c|}
\hline \multicolumn{8}{|c|}{ No. scorable fragments for each probe (restriction enzyme used) ${ }^{\mathrm{z}}$} \\
\hline \multicolumn{8}{|c|}{ Restriction enzyme } \\
\hline Eco RI & Eco RV & Bam HI & Bgl II & Dra I & Hind III & Pst I & XbaI \\
\hline$\overline{\mathrm{AG}} 46(9)$ & AG46 (5) & AG40 (6) & PGlm (7) & Ext (4) & AG11 (3) & AG46 (8) & $\mathrm{AC} 27(6)$ \\
\hline SSU (6) & AG10 (2) & PGlm (3) & AG10 (5) & PGlm (5) & PGlm (11) & PGlm (4) & AG11 (5) \\
\hline Ext (11) & SSU (5) & AG53 (11) & AG53 (7) & & SSU (2) & Ext (3) & PGlm (9) \\
\hline PGlm (13) & Ext (12) & AG10 (2) & SSU (8) & & AC27 (4) & $\mathrm{ADH}(12)$ & SSU (6) \\
\hline AG10 (9) & PGlm (13) & & & & & TPI (2) & AG40 (11) \\
\hline AG53 (8) & APAS (3) & & & & & AG41 (2) & TPI (2) \\
\hline \multirow[t]{2}{*}{$\mathrm{AC} 27$ (8) } & $\mathrm{AC} 27$ (8) & & & & & & \\
\hline & AG53 (8) & & & & & & \\
\hline
\end{tabular}

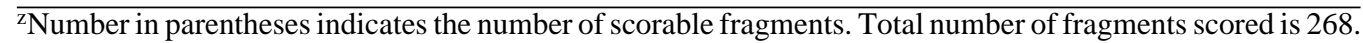
Probes with prefix AG or AC are derived from Prunus genomic or cDNA clones, respectively; PGlm and Ext are from Prunus phosphoglyceromutase and extensin cDNA clones. TPI, ADH, APAS and SSU are Malus triose phosphate isomerase, aminocyclopropane carboxylate synthase, and ribulose bisphosphate carboxylase cDNA clones, respectively. tions in our laboratory. Amplification products were electrophoresed for $9 \mathrm{~cm}$ on gels consisting of a mixture of $1 \%$ UltraPure agarose (Life Technologies) and $1 \%$ NuSieve GTG agarose (FMC, Rockland, Maine) in TAE at $4 \mathrm{~V} \cdot \mathrm{cm}^{-1}$ for $\approx 5 \mathrm{~h}$. Gels were stained with ethidium bromide at $0.35 \mathrm{mg} \cdot \mathrm{mL}^{-1}$. They were visualized under ultraviolet light and then photographed in color (64T Kodak Ektachrome film; Eastman Kodak, Rochester, N.Y.). RAPD product sizes were estimated using a 100-base pair (bp) DNA standard ladder (Life Technologies). The PCR runs generally were performed once; if there was a reaction failure for a particular primer in one or more lanes, the run was repeated with all 16 DNA samples.

The following 39 decamer oligonucleotide primers (Operon Technologies, Alameda, Calif.) used after preselection for reliable amplification of apple DNA were OPA08, OPA17, OPA18, OPA20, OPB07, OPB08, OPB10, OPB13, OPB14, OPB17, OPB18, OPB19, OPB20, OPC01, OPC02, OPC03, OPC04, OPC05, OPC06, OPC07, OPC10, OPC11, OPC13, OPC18, OPC19, OPC20, OPD01, OPD03, OPD04, OPD05, OPD07, OPD10, OPD20, OPF01, OPF03, OPF05, OPF06, OPAM19, and the customized primer 5'CGT CGT GGA A-3'.

Data analysis. Individual isozyme and RAPD bands were scored as present or absent from enlarged color photographs and restriction fragment bands directly from exposed x-ray films (lumigrams). Faint RAPD bands of doubtful reproducibility were ignored, and those that were very faint compared to others in the same position were scored as absent. For RFLP and RAPD marker systems, samples from all 16 cultivars under comparison were run on the same gel, and scoring was double-checked by independent operators.

Genetic distances from 'Braeburn' were calculated for each cultivar using RFLP and RAPD data separately as follows: number of bands not in common $\div$ number of band positions with at least one band. An outlier model was fitted using Gibbs' sampling to test for close pairing with 'Braeburn' as described in Verdinelli and Wasserman (1991).

\section{Results}

Isozyme. Screening of the 186 cultivars for allelic variation of PGM enabled preselection of a subset of cultivars that were possible 'Braeburn' parents. The $b$ allele in PGM-3 was present at a low frequency $(16 \%)$ in the population and was detected as heterozygous in 'Braeburn', indicating that it must be present in one of its parents. Fifteen cultivars were selected for detailed analysis of their relatedness to 'Braeburn' using DNA techniques, including those with the $b$ allele and known either to be present or absent (used as control) in New Zealand in the 1950s. These cultivars included 'Ein Shemer', 'Api Rose', 'Green Square', 'Kalterer Böhmerapfel', 'Lady Hamilton', 'Linda da Insua', 'Lodi', 'Merton Russet', 'Pfinkenwerder Prinzenapfel', 'Pfirsischenroter Sommer', 'Reinette de France', 'Rhymer', 'Roja de Valle de Benejama', 'Winter Banana', and 'Winston'. 
RFLPs. All 15 cultivars and 'Braeburn' were analyzed using all 41 probe-enzyme combinations, resulting in a data set of 268 different scorable restriction fragment bands, two to 13 per probe and 97 to 120 scored positive per cultivar over all probes.

To identify possible parents for 'Braeburn', we first identified sets of RFLP bands (loci) that are probably allelic based on band number per cultivar for all 16 cultivars was 1 or 2 . Three such loci are illustrated on Fig. 1. Each set was scored separately and cultivars were excluded as parents of 'Braeburn' using Mendelian segregation. Figure 1 shows a typical result for the hybridization of Eco RI digests with the AG 46 probe from Prunus. Three independent RFLP loci, labeled I, II, and III, are distinguishable with four, two, and four alleles, respectively, present in the 16 cultivars used in the study. From the banding pattern at locus I, 'Winstone' and 'Rhymer' in lanes 2 and 5 cannot be parents for 'Braeburn' (lane 1). From the banding pattern for locus II, 'Pfirsischenroter Sommer', 'Rhymer', 'Api Rose', 'Green Square', and 'Kalterer Böhmerapfel' in lanes 4, 5, 7, 9, and 13, respectively, cannot be 'Braeburn' parents, while for locus III, only 'Pfirsichenroter Sommer' in lane 4 is excluded. When the overall results (Table 2) are considered, the only cultivar that has not been excluded as a parent is 'Lady Hamilton'. No other cultivar has less than six scores against it and some scored 18 exclusions. The method is stringent, but assumes the correct identification of allelic sets of bands.

Then the entire data set from the 41 probe-enzyme combinations (Table 1) was used to conduct pairwise comparisons for each band between 'Braeburn' and each of the other cultivars by calculating the genetic distance for all 268 bands scored (Table 3 ). 'Lady Hamilton' was closest to 'Braeburn' with a genetic distance of 0.22 , while all other cultivars were further away, ranging from 0.41 to 0.62 .

The outlier model using Gibbs' sampling demonstrated that the distribution of the genetic distances for unrelated cultivars was well approximated using a normal distribution for RFLPs with a mean of $0.53(\mathrm{SD}=0.05)$. The outlier probability estimate for the pair 'Braeburn' - 'Lady Hamilton' was 1.000. The posterior distribution for the genetic distance for this pair had a mean of 0.22 (SD $=0.05)$ compared to $0.53(\mathrm{SD}=0.05)$ for all others. All other points had very low or zero outlier probabilities.

RAPDs. Distinct and reproducible RAPD profiles have been obtained with 39 selected primers, and these have allowed scoring of 279 to 309 positive bands per cultivar. The total number of bands scored is 487 ( 4 to 21 bands per primer). Figure 2 shows two sets of RAPD profiles from this study that demonstrate the heterozygosity revealed in apple by this technique. All 16 cultivars under investigation can be distinguished based on their RAPD profiles with primer OPB10 in the amplification reaction. The RAPDs amplified with primer OPB 13 are almost as powerful for differentiating the cultivars; only the profiles for 'Api Rose' and 'Kalterer Böhmerapfel' are indistinguishable.

The RAPD data set was analyzed using only genetic distance calculations because the dominant-recessive mode of inheritance of RAPD bands precluded using them to exclude cultivars from parentage. Although the genetic distances of all 15 cultivars to 'Braeburn' in Table 4 extended over a range half that calculated earlier from restriction fragments ( 0.20 vs. 0.40$)$, 'Lady Hamilton' remained closest to 'Braeburn' at 0.23 . The next cultivar, 'Lodi' was at 0.08 distance from 'Lady Hamilton', and a group of 13 cultivars excluding 'Lady Hamilton' and 'Api Rose' clustered over 0.07 units between 0.32 to 0.39 . The distance for 'Api Rose' was 0.04 further away from 'Braeburn' than the lowest value in this grouping.
The distribution of genetic distances for RAPDs was well approximated by a normal distribution with a mean of $0.38 \pm 0.03$ (SD). For RAPD data as for RFLPs, the pair 'Braeburn'-'Lady Hamilton' was closest at a genetic distance of 0.23 and did not stand out as much from the overall distribution of distances as observed with RFLP analysis. There were no outliers detected for RAPD data.

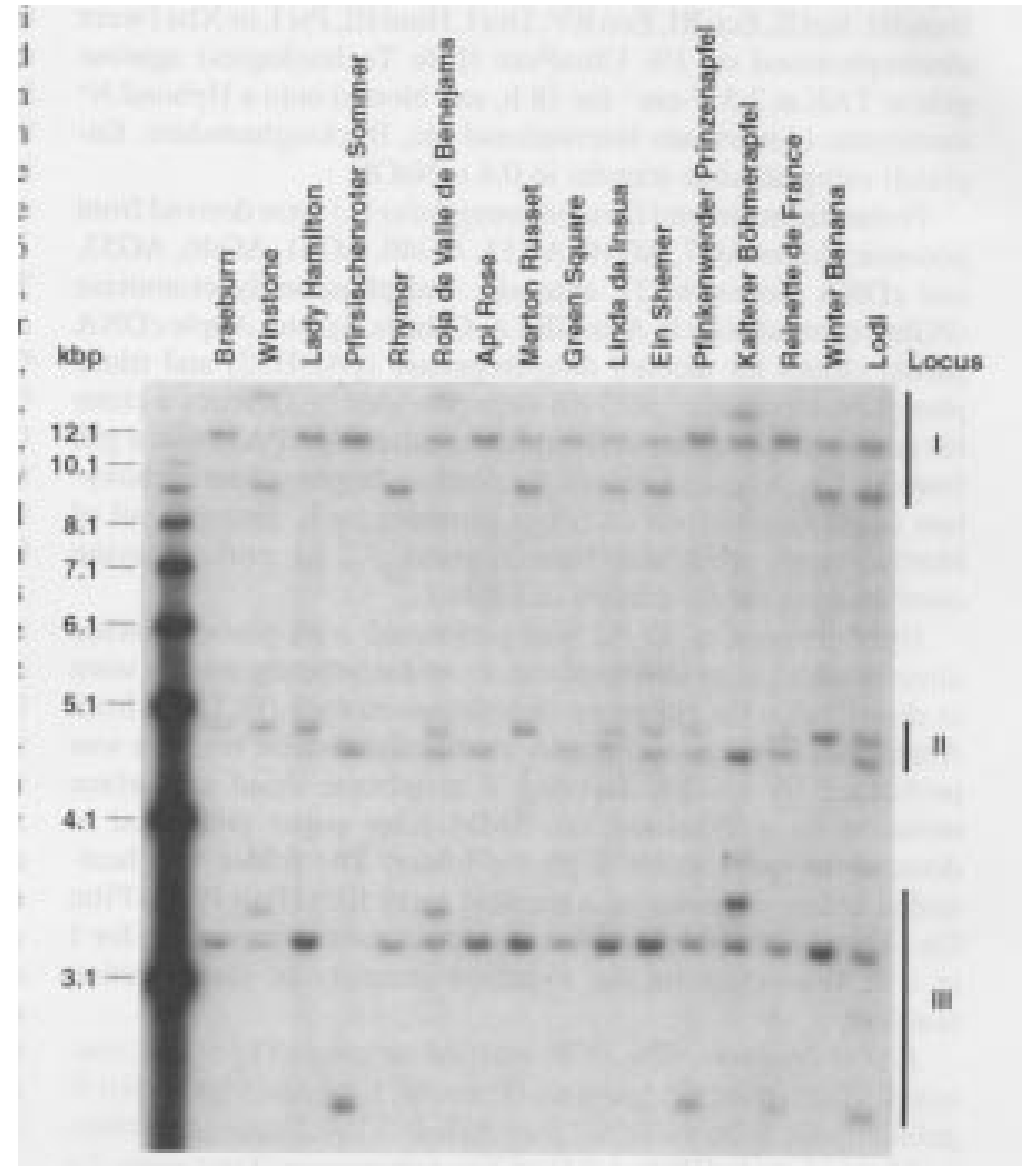

Fig. 1. RFLP profiles for an Eco RI digest of apple DNA probed with the genomic probe AG40 from Prunus amygdalus using a chemiluminescent detection technique following 4-h exposure to an x-ray film. Lane 1 is a 1-kilobase DNA molecular size standard from Life Technologies, Gaithersburg, Md.

Table 2. Scoring of assumed allelic restriction fragments from 15 cultivars to exclude cultivars for parentage of 'Braeburn'.

\begin{tabular}{lc}
\hline Cultivar & $\begin{array}{c}\text { No. exclusions/probe } \\
\text { (enzyme combination) }\end{array}$ \\
\hline Lady Hamilton & 0 \\
Merton Russet & 6 \\
Winston & 7 \\
Reinette de France & 8 \\
Winter Banana & 9 \\
Roja de Valle de Benejama & 10 \\
Api Rose & 10 \\
Green Square & 11 \\
Pfirsischenroter Sommer & 12 \\
Linda da Insua & 14 \\
Finkenwerder Prinzenapfel & 14 \\
Lodi & 15 \\
Kalterer Böhmerapfel & 18 \\
Ein Shemer & 18 \\
Rhymer & 18 \\
\hline
\end{tabular}




\section{Discussion}

'Lady Hamilton' is an Australian cultivar of unknown parentage, and there are reports indicating that it was growing in an orchard nearby where 'Braeburn' was first identified (R. Hart,

Table 3. Genetic distances between 'Braeburn' and 15 other cultivars calculated from restriction fragments.

\begin{tabular}{lc}
\hline \hline Cultivar & Genetic distance $^{\mathrm{z}}$ \\
\hline Lady Hamilton & 0.22 \\
Winston & 0.41 \\
Merton Russet & 0.48 \\
Pfirsischenroter Sommer & 0.49 \\
Api Rose & 0.49 \\
Reinette de France & 0.50 \\
Green Square & 0.50 \\
Roja de Valle de Benejama & 0.51 \\
Winter Banana & 0.53 \\
Finkenwerder Prinzenapfel & 0.55 \\
Rhymer & 0.56 \\
Kalterer Böhmerapfel & 0.58 \\
Lodi & 0.58 \\
Linda da Insua & 0.60 \\
Ein Shemer & 0.62 \\
\hline
\end{tabular}

$\overline{{ }^{\mathrm{z}} \text { The genetic distance was calculated as follows: number of RFLP bands }}$ not in common $\div$ number of band positions with at least one band. personal communication). Because of similarities in fruit characters between the two cultivars, it has been speculated that 'Lady Hamilton' is the female parent of 'Braeburn' or even that the two cultivars are identical. The results of RFLP and RAPD analyses (Figs. 1 and 2, Tables 3 and 4) clearly indicate that 'Braeburn' and 'Lady Hamilton' are not genetically identical as both types of molecular profiles have exhibited variation between these cultivars. However, some probe-enzyme combinations (e.g., Fig. 1) and RAPD primers have failed to distinguish between them, thus suggesting relatedness.

'Lady Hamilton' was the only cultivar among the 15 preselected on PGM-3 genotype not to be excluded from parentage of 'Braeburn' based on RFLP banding associations. The number of exclusions from parentage ranged from six to 18 each for the remaining 14 cultivars examined using 41 probe-enzyme combinations.

The large number of fragments analyzed for RFLPs (268) and RAPDs (487) has allowed determination of genetic distances of the 15 preselected cultivars relative to 'Braeburn', with 'Lady Hamilton' being the closest. The 'Braeburn'-'Lady Hamilton' pair had an outlier probability of 1.0, thus providing evidence for relatedness and possible parentage. The model used gives as output posterior probabilities for individual data points to be outliers. Data points not outliers are assumed to come from a single normal distribution. Outliers are pairs whose distances are large enough to stand out from the overall distribution of the data, and we have interpreted a posterior outlier probability near one as evidence for relatedness.
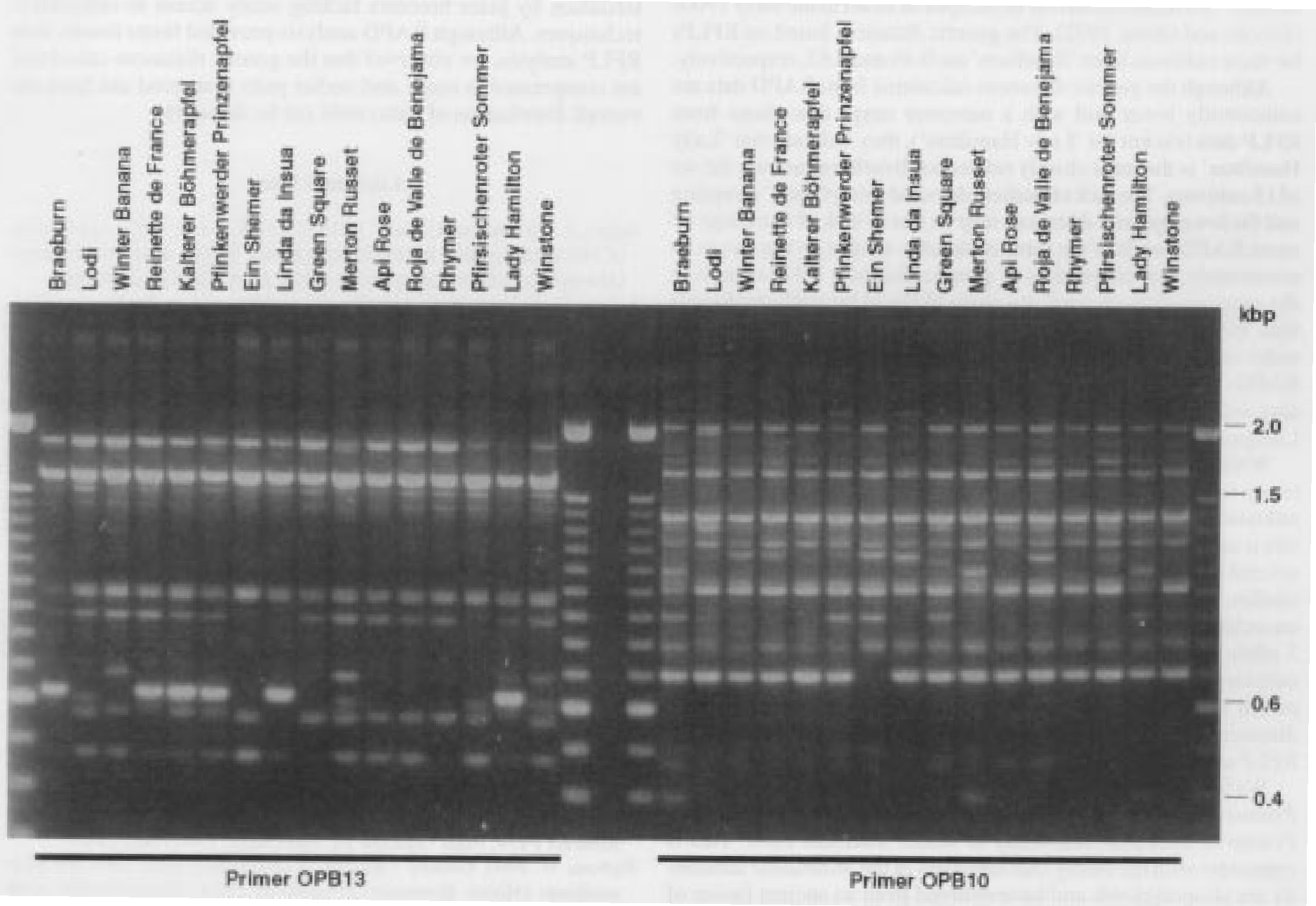

Fig. 2. RAPD profiles for the 16 named apple cultivars using primers OPB13 and OPB10. The first and last lane within each gel corresponds to a 100-base pair DNA molecular size standard (Life Technologies). 
Nybom (1990) used a microsatellite probe to hybridize apple DNA digested with Taq 1 (eight to 10 informative fragments per genotype) and obtained values for similarity indices (Wetton et al., 1987), which might be expected for different degrees of relatedness. She reported an average similarity index of 0.71 for five maternal genotypes of ornamental crab apples and their offspring, while comparisons between sibs and half-sibs gave a value of 0.63 and the bandsharing between unrelated individuals was 0.41. Calculation of similarity indices between 'Braeburn' and the other cultivars used in our study using the formula: similarity index $=2$ $\times$ number of shared bands $\div$ number of bands in genotype $\mathrm{A}+$ number of bands in genotype $\mathrm{B}$ gave values that were higher overall and ranged from 0.89 for 'Lady Hamilton' to 0.55 for 'Ein Shemer'. The similarity index obtained for the 'Lady Hamilton''Braeburn' pair (0.89) was consistent with a parent-offspring relationship.

It is likely that other cultivars in this study are more distantly related to 'Braeburn', and in this respect, it is interesting to note that 'Braeburn' is regarded as having 'Cox'-type flavor characteristics. 'Winston' is known to have 'Cox's Orange Pippin' ancestry (Smith, 1971) and is the second closest to 'Braeburn' in genetic distance measurements using RFLPs.

The ancient dessert apple 'Api Rose' (used as a control) is of Roman origin (Hogg, 1875; Smith, 1971) and is not a parent of 'Braeburn' due to its small fruit size, which is transmitted to its progeny. Moreover, there is no record that 'Api Rose' has been present in the Nelson region in 1952. The second control 'Ein Shemer' is a modern cultivar developed in Israel in the early $1960 \mathrm{~s}$ (Brooks and Olmo, 1972). The genetic distances based on RFLPs for these cultivars from 'Braeburn' are 0.49 and 0.62 , respectively.

Although the genetic distances calculated from RAPD data are consistently lower and with a narrower range than those from RFLP data (except for 'Lady Hamilton'), they indicate that 'Lady Hamilton' is the most closely related to 'Braeburn' among the set of 15 cultivars. The lack of outliers detected using Gibbs' sampling and the lower genetic distances may be due to lack of homology of some RAPD bands of the same molecular weight giving rise to an erroneously low calculation of genetic distance. RAPD bands at the same position on a gel are more likely to be nonhomologous than RFLP bands, which may contribute to the variation in the order of the cultivars for genetic distances between RFLPs and RAPDs (Thormann and Osborn, 1992). The dominance of RAPDs also will result in a higher bandsharing than expected (Clark and Lanigan, 1993).

While it is impossible to prove that 'Lady Hamilton' definitively is one of the parents of 'Braeburn' when both parents are unknown, our results indicate that there is a high likelihood that this is so, and we have shown the use of a concerted approach with several types of biochemical and molecular markers for parentage studies. 'Lady Hamilton', which is known to have been present in an orchard nearby to the 'Braeburn' seedling, shares the rare PGM3 allele $b$ with 'Braeburn' and is the only cultivar in a set of 15 cultivars tested carrying this allele that can not be excluded as a parent based on RFLP segregation data. Moreover, its genetic distance from 'Braeburn' is the lowest of all cultivars used for RFLP and RAPD analyses.

We found that there is a sufficient degree of homology between Prunus and Malus genomes for genomic and cDNA probes from Prunus to hybridize efficiently to Malus Southern blots. This is consistent with the theory that members of the Maloideae subfamily are allopolyploids and have evolved from an ancient fusion of members of the Prunoideae subfamily with other members of the Rosaceae family (Chevreau et al., 1985; Sax, 1933)
Table 4. Genetic distances calculated from RAPD products for 15 cultivars compared with 'Braeburn'.

\begin{tabular}{lc}
\hline \hline Cultivar & Genetic distance $^{z}$ \\
\hline Lady Hamilton & 0.23 \\
Lodi & 0.31 \\
Reinette de France & 0.32 \\
Green Square & 0.32 \\
Finkenwerder Prinzenapfel & 0.33 \\
Merton Russet & 0.33 \\
Winter Banana & 0.35 \\
Winston & 0.36 \\
Pfirsischenroter Sommer & 0.36 \\
Kalterer Böhmerapfel & 0.36 \\
Rhymer & 0.37 \\
Roja de Valle de Benejama & 0.39 \\
Linda da Insua & 0.39 \\
Ein Shemer & 0.39 \\
Api Rose & 0.43
\end{tabular}

${ }^{\mathrm{z} T h e}$ genetic distance was calculated as follows: number of RAPD bands not in common $\div$ number of band positions with a least one band.

A chemiluminescent method has provided an effective alternative to radioactive detection in apple for homologous and heterologous genomic and cDNA RFLP probes. We initially demonstrated using chemiluminescent detection in apple using an M13 probe (Nybom et al., 1992) and have suggested its use for DNA characterization by plant breeders lacking ready access to radioactive techniques. Although RAPD analysis provided faster results than RFLP analysis, we observed that the genetic distances calculated are compressed in range and outlier pairs that stood out from the overall distribution of data could not be detected.

\section{Literature Cited}

Adato, A., D. Sharon, U. Lavi, J. Hillel, and S. Gazit. 1995. Application of DNA fingerprints for identification and genetic analysis of mango (Mangifera indica) genotypes. J. Amer. Hort. Sci. 120:259-264.

Boury, S., I. Lutz, M-C. Gavalda, F. Guidet, and A. Schlesser. 1992. Empreintes genetiques du chou-fleure par RAPD et verification de la purete hybride F1 d'un lot de semences. Agronomie 12:669-681.

Brooks, R.M. and H.P. Olmo. 1972. Register of new fruit and nut varieties. 2nd ed. Univ. of California Press, Berkeley.

Chevreau, E., Y. Lespinasse, and M. Gallet. 1985. Inheritance of pollen enzymes and polyploid origin of apple (Malus $\mathrm{x}$ domestica Borkh.). Theor. Appl. Genet. 71:268-277.

Chyi, Y.S. and N.F. Weeden. 1984. Relative isozyme band intensities permit the identification of the $2 \mathrm{n}$ gamete parent of triploid apple cultivars. HortScience 19:818-819.

Clark, A.G., and C.M.S. Lanigan. 1993. Prospects for estimating nucleotide divergence with RAPDs. Mol. Biol. Evol. 10:1096-1111.

Harada, T., K. Matsukawa, T. Sato, R. Ishikawa, M. Niizeki, and K. Saito. 1993. DNA-RAPDs detect genetic variation and paternity in Malus. Euphytica 65:87-91.

Hogg, R. 1875. The fruit manual. 4th ed. J. Hort. Office, London.

Landry, B.S., R.Q. Li, W.Y. Cheung, and R.L. Granger. 1994. Phylogeny analysis of 25 apple rootstocks using RAPD markers and tactical gene tagging. Theor. Appl. Genet. 89:847-852.

Noli, E., S. Salvi, and R. Tuberosa. 1995. Analysis of the genetic relationships among barley cultivars using RFLP and RAPD markers. Abstract P174, Plant Genome III, San Diego, 15-19 Jan. 1995.

Nybom, H. 1990. Genetic variation in ornamental apple trees and their seedlings (Malus, Rosaceae) revealed by DNA 'fingerprinting' with the M13 repeat probe. Hereditas 113:17-28.

Nybom, H., S.E. Gardiner, and C.J. Simon. 1992. RFLPs obtained from 
an rDNA probe and detected with enhanced chemiluminescence in apples. HortScience 27:355-356.

Nybom, H. and B.A. Schaal. 1990. DNA "fingerprints" applied to paternity analysis in apples (Malus $\mathrm{x}$ domestica). Theor. Appl. Genet. 79:763-768.

Sax, K. 1933. The origin of the Pomoideae. J. Amer. Soc. Hort. Sci. 30:147-150.

Smith, M.W.G. 1971. The national apple register of the United Kingdom. Ministry of Agriculture, Fisheries and Food, London.

Taylor, M. 1995. The blooming of Braeburn. Orchardist of N.Z. 68:31-34.

Thormann, C.E. and T.C. Osborn. 1992. Use of RAPD and RFLP markers for germplasm evaluation, p. 9-11. In: Applications of RAPD technology to plant breeding. Crop Sci. Soc. Amer., Madison, Wis.
Verdinelli, I. and L. Wasserman. 1991. Bayesian analysis of outlier problems using the Gibbs sampler. Stat. and Computing 1:105-117.

Watillon, B., P. Druart, P. Du Jardin, R. Kettmann, P. Boxus, and A. Burny. 1991. Use of random cDNA probes to detect restriction fragment length polymorphisms among apple clones. Scientia Hort. 46:235-243.

Weeden, N.F. and R.C. Lamb. 1985. Identification of apple cultivars by isozyme phenotypes. J. Amer. Soc. Hort. Sci. 110:509-515.

Wendel, J.F. and N.F. Weeden. 1989. Visualization and interpretation of plant isozymes, p. 5-45. In: D.E. Soltis and P.S. Soltis (eds.). Isozymes in plant biology. Dioscorides Press, Portland, Ore.

Wetton, J.H., R.E. Carter, D.T. Parkin, and D. Walters. 1987. Demographic study of a wild house sparrow population by DNA fingerprinting. Nature 327:147-149. 